\title{
Irrigation Water Management for Sunflower Production at North Nile Delta Soils
}

\author{
A.S. El-Henawy ${ }^{*}$ and Eman M.K.E. Soltan ${ }^{* *}$ \\ "Soils and Water Department, Faculty of Agriculture, \\ Kafr El-Sheikh University and "Nepartment of Plant Physiology, \\ Agriculture Research Station, Sakha, Kafr El-sheikh, ARC, Egypt.
}

\begin{abstract}
TWO field experiments were conducted at El-Karada water management station, Kafr El- Sheikh Governorate, Egypt during two successive summer seasons 2008 and 2009, to study the effect of irrigation water management for sunflower production through irrigation escaping of some irrigation events, during the growth season on yield, yield components and quality of sunflower crop. Randomized complete block design with three replications was used. The irrigation treatments included five treatments, conventional irrigation along the growing season every 15 days $\left(\mathrm{T}_{1}\right)$, escaping irrigation at the age of 30 days from sowing $=3^{\text {rd }}$ irrigation $\left(\mathrm{T}_{2}\right)$, escaping irrigation at the age of 45 days from sowing $=4^{\text {th }}$ irrigation $\left(T_{3}\right)$, escaping irrigation at the age of 60 days from sowing $=5^{\text {th }}$ irrigation $\left(\mathrm{T}_{4}\right)$ and escaping irrigation at the age of 75 days from sowing $=6^{\text {th }}$ irrigation $\left(\mathrm{T}_{5}\right)$.
\end{abstract}

The highest values of seed yield, oil percent, oil yield and 100 seed weight were obtained under $\mathrm{T}_{4}$ as well as the highest net return of water unit and economic efficiency. Therefore, escaping sunflower irrigation at the age of 60 days from sowing (the $5^{\text {th }}$ irrigation) could be recommended to maximize sunflower production under the condition of studied area.

Keywords: Sunflower yield, Oil yield, Net return of water unit and economic efficiency.

Sunflower is considered one of the most promising oil crops in Egypt. It is proposed to close up the gap of oil consumption. At present, Egypt imports about $80-85 \%$ of its annual requirements of edible vegetable oils. A possible remedy to the present gap between the domestic production and demand for edible oil could be achieved by conduction numerous investigation about the effect of fertilization, sowing dates and irrigation treatments on maximizing the productivity of sunflower under local climatic conditions. Because of the water limitation faced Egypt, we should do our best towards effective rationalization of irrigation at farm level. Several investigators have been studied the effect of irrigation treatments on yield and its components of sunflower plants. Deficit irrigation has been considered worldwide as a way of maximizing water use efficiency by eliminating irrigations that have little impact on yield (English, 1990, English and Raja, 1996 and Kirda et al., 1999). Moreover, Kirnak et al.

e-mail : aelhenawy @ yahoo.com 
(2002) pointed out that yield loss which may result from deficit irrigation is offset by the benefit of reduced water use. Stone et al. (1996) reported that when water is limiting, water stress could be scheduled during milking stages, while during flowering water stress should be avoided. In that sense, Tan et al. (2000) and Rinaldi (2001) found that irrigation at flowering produced the highest net income in sunflower production. Karam et al. (2007) indicated that irrigation limitation at early and mid flowering should be avoided while it can be acceptable at seed formation. The objective of this study was to manage the irrigation water for sunflower by irrigation with holding of some irrigation events during the season on the yield and its components and yield quality as well as economic return.

\section{Material and Methods}

The present investigation was carried out at El-Karada water management station Farm, Kafr El-Sheikh Governorate during two successive summer seasons 2008 and 2009. Kafr El-Sheikh is located at $31^{\circ} 07^{-} \mathrm{N}$ latitude and $30^{\circ}$ $52 \mathrm{E}$ longitude and has elevation about $6 \mathrm{~m}$ above sea level. The soil of studied site is clay in texture. The main analytical values were, clay $51.7 \%$, silt $26.1 \%$, sand $22.2 \%$, EC $2.59 \mathrm{dS} \mathrm{m}^{-1}$ in soil paste extract, $\mathrm{pH} 8.05$, organic matter 13.8 $\mathrm{g} \mathrm{kg}^{-1}$, field capacity $44.7 \%$ and wilting percent 24.2 . Randomized complete block design with three replications was used in both seasons. The irrigation treatments included five treatments as follows:-

$\mathrm{T}_{1}$ : Conventional irrigation along the growing season every 15 days (control).

$\mathrm{T}_{2}$ : Escaping irrigation at the age of 30 days after sowing (DAS), ( $3^{\text {rd }}$ irrigation).

$\mathrm{T}_{3}$ : Escaping irrigation at the age of $45 \mathrm{DAS},\left(4^{\text {th }}\right.$ irrigation $)$.

$\mathrm{T}_{4}$ : Escaping irrigation at the age of $60 \mathrm{DAS},\left(5^{\text {th }}\right.$ irrigation $)$.

$\mathrm{T}_{5}$ : Escaping irrigation at the age of $75 \mathrm{DAS},\left(6^{\text {th }}\right.$ irrigation $)$.

Each plot area was $42 \mathrm{~m}^{2}$ including 10 ridges, $7 \mathrm{~m}$ long and $0.60 \mathrm{~cm}$ apart. Plots were isolated by ditches of $1.5 \mathrm{~m}$ in width to avoid lateral movement of water. Seed of sunflower cultivar Sakha 53 was sown on March 15 ${ }^{\text {th }}, 2008$ and $19^{\text {th }}, 2009$ at hills $20 \mathrm{~cm}$ apart on one side of the ridges and harvested on July 7 and 17 in both seasons, respectively. In both seasons, phosphorous fertilizer in the form of calcium super phosphate $\left(15.5 \% \mathrm{P}_{2} \mathrm{O}_{5}\right)$ was applied at the rate of 30 $\mathrm{kg} \mathrm{P}_{2} \mathrm{O}_{5} /$ fed during land preparation. Nitrogen was added in the form of urea $46 \% \mathrm{~N}$ ) at the rate of $40 \mathrm{~kg} \mathrm{~N} / \mathrm{fed}$ in two equal doses before the first and second irrigations, respectively. Potassium was added in the form of potassium sulphate $\left(48 \% \mathrm{~K}_{2} \mathrm{O}\right)$ at the rate of $24 \mathrm{~kg} \mathrm{~K} \mathrm{~K}_{2} \mathrm{O} / \mathrm{fed}$. Thinning practices were conducted after 21 days from planting to sear one plant per hill. Other practices for growing sunflower were conducted as recommended by Ministry of Agriculture and Land Reclamation (2006). Ten guarded plants were randomly taken from the fourth inner ridges to determine yield components. Sunflower seed was obtained from central area of each treatment to avoid any border effect.

Egypt. J. Soil Sci. 53, No. 1 (2013) 
The following traits were measured, i.e., 100-seed weight, seed yield per plant, seed oil percent, seed and oil yield in $\mathrm{Mg} \mathrm{ha}^{-1}$. Seed oil percent was determined using soxhlet extraction unit as reported by A.O.A.C (2005). Seed oil yield was calculated by multiplying seed yield in $\mathrm{Mg} \mathrm{ha}^{-1}$ by seed oil percent.

Irrigation water was applied through a weir and the water amount (Table 1) was calculated by using the following equation:

$\mathrm{Q}=1.84 \mathrm{LH}^{1.5}$

Where: $\mathrm{Q}=$ Rate of discharge, $\mathrm{m}^{3} / \mathrm{sec}$.

$\mathrm{L}=$ length edge of weir, $\mathrm{cm}$.

$\mathrm{H}=$ Height of water above edge of weir, $\mathrm{cm}$.

The obtained data were subjected to analysis of variance according to Gomez and Gomez (1984). Treatment means were compared by Duncan's Multiple Range Test (Duncan, 1955). All statistical analysis was performed using analysis of variance technique by means of "MSTATC" computer software package.

TABLE 1. Amount of irrigation water applied ( $\left.\mathrm{m}^{3} / \mathrm{fed}\right)$ to sunflower crop, under the different treatments, during two growing seasons $2008,2009$.

\begin{tabular}{|l|c|c|c|c|c|}
\hline \multirow{2}{*}{ Seasons } & \multicolumn{5}{|c|}{ Treatments } \\
\cline { 2 - 6 } & $\mathbf{T}_{\mathbf{1}}$ & $\mathbf{T}_{\mathbf{2}}$ & $\mathbf{T}_{\mathbf{3}}$ & $\mathbf{T}_{\mathbf{4}}$ & $\mathbf{T}_{\mathbf{5}}$ \\
\hline 2008 & 2823.9 & 2447.4 & 2303.9 & 2296.4 & 2282.4 \\
\hline 2009 & 2795.0 & 2435.0 & 2320.0 & 2301.0 & 2299.0 \\
\hline
\end{tabular}

\section{Results and Discussions}

Effect of irrigation water escaping on yield and yield components of sunflower crop

Data in Table 2 presented the effect of irrigation water escaping on 100 seeds weight, seed yield, oil percent and oil yield.

Weight of 100 seed was significantly affected by irrigation water escaping treatments in $1^{\text {st }}$ and $2^{\text {nd }}$ season. The highest values $(7.15$ and $6.06 \mathrm{~g})$ were found under $\mathrm{T}_{4}$ in the two growing seasons 2008 and 2009, respectively. While, the lowest ones (5.99 and $5.14 \mathrm{~g}$ ) were found under $\mathrm{T}_{2}$ and $\mathrm{T}_{3}$ in the same growing seasons, respectively. The lowest yield recorded under $T_{2}$ and $T_{3}$ could be attributed to that irrigation escaping was occurred during the flowering and the seed formation stages. These results are in the same trend of Doorenbos and Kassam (1979) who showed that seed formation is the next most sensitive period to water deficit, causing severe reduction in both yield and oil content.

Seed yield (Mg/fed) was significantly affected by irrigation water escaping treatments. The highest values of seed yield were obtained under $\mathrm{T}_{4}$ and the lowest ones were obtained under $T_{2}$ in the two growing seasons. These results were in agreement with those obtained by Browne (1977) who showed that yield losses are generally greatest when water stress occurs in the period 20

Egypt. J. Soil Sci. 53, No. 1 (2013) 
days prior to flowering. He also reported that seed yield increased by $30 \%$ from irrigation at 2 weeks after mid-flowering. The highest yield under T4 could be attributed to the irrigation escaping at 60 DAS (the $5^{\text {th }}$ irrigation) which acts as a trigger for the physiological processes that actually increase yield (Smith et al., 2002). Severe water deficits during the early vegetative growth result in reduced plant height but may increase root depth. Adequate water during the late vegetative period is required for proper bud development. The flowering period is the most sensitive to water deficits which cause considerable yield decrease since fewer flower come to full development (Beyazgul et al., 2000 and Ali \& Shui, 2009).

TABLE 2. Effect of irrigation escaping on yield and yield components of sunflower crop.

\begin{tabular}{|c|c|c|c|c|}
\hline Treatments & $\begin{array}{c}100 \text { seeds } \\
\text { weight }(g)\end{array}$ & $\begin{array}{c}\text { Seed yield } \\
\left(\mathrm{Mg} \mathrm{ha}^{-1}\right)\end{array}$ & $\begin{array}{c}\text { Oil in seeds } \\
(\%)\end{array}$ & $\begin{array}{r}\text { Oil yield } \\
\left(\mathrm{Mg} \mathrm{ha}^{-1}\right)\end{array}$ \\
\hline \multicolumn{5}{|c|}{ Season 2008} \\
\hline $\mathrm{T}_{1}$ & $6.12 b$ & $3.16 \mathrm{a}$ & 41.3 & $1.31 \mathrm{a}$ \\
\hline $\mathrm{T}_{2}$ & $5.99 \mathrm{~b}$ & $2.72 \mathrm{~b}$ & 41.5 & $1.13 \mathrm{~b}$ \\
\hline $\mathrm{T}_{3}$ & $7.04 \mathrm{a}$ & $2.97 \mathrm{ab}$ & 41.8 & $1.23 \mathrm{~b}$ \\
\hline $\mathrm{T}_{4}$ & $7.15 \mathrm{a}$ & $3.41 \mathrm{a}$ & 41.9 & $1.43 \mathrm{a}$ \\
\hline $\mathrm{T}_{5}$ & $6.46 \mathrm{ab}$ & $2.94 \mathrm{ab}$ & 41.1 & $1.21 \mathrm{ab}$ \\
\hline F-test & $* *$ & $*$ & ns & $*$ \\
\hline \multicolumn{5}{|c|}{ Season 2009} \\
\hline $\mathrm{T}_{1}$ & $5.74 \mathrm{a}$ & $3.16 \mathrm{a}$ & $40.9 \mathrm{a}$ & $1.23 \mathrm{ab}$ \\
\hline $\mathrm{T}_{2}$ & $5.81 \mathrm{a}$ & $2.69 \mathrm{~b}$ & $41.7 \mathrm{a}$ & $1.27 \mathrm{a}$ \\
\hline $\mathrm{T}_{3}$ & $5.14 \mathrm{~b}$ & $2.95 \mathrm{~b}$ & $38.7 \mathrm{~b}$ & $1.19 \mathrm{~b}$ \\
\hline $\mathrm{T}_{4}$ & $6.06 \mathrm{a}$ & $3.41 \mathrm{a}$ & $41.7 \mathrm{a}$ & $1.32 \mathrm{a}$ \\
\hline $\mathrm{T}_{5}$ & $5.83 \mathrm{a}$ & $3.18 \mathrm{a}$ & $39.7 \mathrm{~b}$ & $1.15 \mathrm{~b}$ \\
\hline F-test & $*$ & $*$ & $*$ & $*$ \\
\hline
\end{tabular}

, ${ }^{* * *}$ and $\mathrm{ns}$ indicate $\mathrm{p}<0.05, \mathrm{p}<0.01$ and not significant, respectively. Means for each factor designed by the same letter are not significantly different at $5 \%$ level using Duncan's MRT.

Oil percent in seeds of sunflower is considered as character of yield quality. It was not significantly affected by irrigation water escaping treatments in the $1^{\text {st }}$ season but, significantly affected in the $2^{\text {nd }}$ season. The highest values of oil percent were obtained under $\mathrm{T}_{4}$ in two seasons.

Oil yield was significantly affected by irrigation water treatments in the two growing seasons. The highest values of oil yield were obtained under $T_{4}$ in two seasons. The lowest values of oil yield were obtained under $T_{2}$ and $T_{5}$ in 2008 and 2009, respectively. Kazemeini et al. (2009) showed that irrigation levels significantly affected seed yield and oil percentage. Their results indicated that deficit irrigation, during the critical growth period should be avoided. 
Effect of irrigation water escaping on net income and economic feasibility of sunflower crop.

Data in Table 3 present the total cost of sunflower production in two growing seasons 2008 and 2009. The cost of production included fixed and variable costs. Fixed costs is similar in all treatments, while variable costs is higher in $\mathrm{T}_{1}$ (control) than in the others by 20 Egyptian Pound (LE), which is the cost of the excess irrigation events (one irrigation). Variable cost in $1^{\text {st }}$ season was higher than the $2^{\text {nd }}$ one by about $140 \mathrm{LE}$ due to the increase of chemical fertilizers prices.

TABLE 3. Total cost of sunflower production, LE*/ fed in seasons 2008 and 2009.

\begin{tabular}{|l|c|c|c|c|c|}
\hline \multirow{2}{*}{ Input } & \multicolumn{5}{|c|}{ Treatments } \\
\cline { 2 - 6 } & $\mathbf{T}_{\mathbf{1}}$ & $\mathbf{T}_{\mathbf{2}}$ & $\mathbf{T}_{\mathbf{3}}$ & $\mathbf{T}_{\mathbf{4}}$ & $\mathbf{T}_{\mathbf{5}}$ \\
\hline Reasons 2008 \\
\hline Land preparation & 2500 & 2500 & 2500 & 2500 & 2500 \\
\hline Seeds and seeding & 300 & 300 & 300 & 300 & 300 \\
\hline irrigation & 200 & 200 & 200 & 200 & 200 \\
\hline Hand hoeing and weed control & 120 & 100 & 100 & 100 & 100 \\
\hline fertilizers & 140 & 140 & 140 & 140 & 140 \\
\hline Harvesting & 570 & 570 & 570 & 570 & 570 \\
\hline Total & 400 & 400 & 400 & 400 & 400 \\
\hline & $\mathbf{4 2 3 0}$ & $\mathbf{4 2 1 0}$ & $\mathbf{4 2 1 0}$ & $\mathbf{4 2 1 0}$ & $\mathbf{4 2 1 0}$ \\
\hline Rent of land & Season $\mathbf{2 0 0 9}$ & & & \\
\hline Land preparation & 2500 & 2500 & 2500 & 2500 & 2500 \\
\hline Seeds and seeding & 300 & 300 & 300 & 300 & 300 \\
\hline irrigation & 200 & 200 & 200 & 200 & 200 \\
\hline Hand hoeing and weed control & 120 & 100 & 100 & 100 & 100 \\
\hline fertilizers & 140 & 140 & 140 & 140 & 140 \\
\hline harvesting & 430 & 430 & 430 & 430 & 430 \\
\hline Total & 400 & 400 & 400 & 400 & 400 \\
\hline I fed 4200 & $\mathbf{4 0 9 0}$ & $\mathbf{4 0 7 0}$ & $\mathbf{4 0 7 0}$ & $\mathbf{4 0 7 0}$ & $\mathbf{4 0 7 0}$ \\
\hline
\end{tabular}

$1 \mathrm{fed}=4200 \mathrm{~m}^{2}, 1 \$ \equiv 5.43 \mathrm{LE}$ in $2008,1 \$ \equiv 5.54 \mathrm{LE}$ in 2009 as annual average.

The effect of irrigation water escaping on net income, total costs, net return, net return of water unit and economic efficiency are presented in Table 4. The economic return was calculated considering the price of one $\mathrm{kg}$ of sunflower seeds was $6 \mathrm{LE}$ in $1^{\text {st }}$ season and $7 \mathrm{LE}$ in $2^{\text {nd }}$ season (average price in local market).

Data showed that the highest value of net income was under $\mathrm{T}_{4}(8600$ and 9937.4 LE) in the $1^{\text {st }}$ and $2^{\text {nd }}$ seasons, respectively. $\mathrm{T}_{4}$ give the highest value of the net return (4390 and 5867.4 LE) in the first and the second seasons, respectively. 
TABLE 4. Effect of irrigation escaping on net income and economic feasibility of sunflower crop.

\begin{tabular}{|c|c|c|c|c|c|}
\hline Treatments & $\begin{array}{l}\text { Net income } \\
\left(\text { LE fed }^{-1}\right)\end{array}$ & $\begin{array}{l}\text { Total costs } \\
\left(\mathrm{LE} \mathrm{fed}^{-1}\right)\end{array}$ & 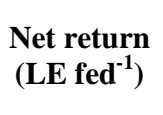 & 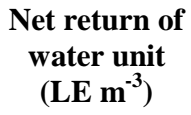 & $\begin{array}{l}\text { Economic } \\
\text { efficiency }\end{array}$ \\
\hline \multicolumn{6}{|c|}{ Season 2008} \\
\hline $\mathrm{T}_{1}$ & 7976 & 4230 & 3746 & 1.33 & 0.886 \\
\hline $\mathrm{T}_{2}$ & 6822 & 4210 & 2662 & 1.09 & 0.632 \\
\hline $\mathrm{T}_{3}$ & 7514 & 4210 & 3304 & 1.43 & 0.785 \\
\hline $\mathrm{T}_{4}$ & 8600 & 4210 & 4390 & 1.91 & 1.043 \\
\hline $\mathrm{T}_{5}$ & 7442 & 4210 & 3232 & 1.42 & 0.768 \\
\hline \multicolumn{6}{|c|}{ Season 2009} \\
\hline $\mathrm{T}_{1}$ & 9224 & 4090 & 5214.3 & 1.84 & 1.275 \\
\hline $\mathrm{T}_{2}$ & 7923 & 4070 & 3853.6 & 1.58 & 0.947 \\
\hline $\mathrm{T}_{3}$ & 8676 & 4070 & 4686.9 & 2.02 & 1.152 \\
\hline $\mathrm{T}_{4}$ & 9937 & 4070 & 5867.4 & 2.55 & 1.442 \\
\hline $\mathrm{T}_{5}$ & 8591 & 4070 & 4521.8 & 1.97 & 1.111 \\
\hline
\end{tabular}

Data also showed that the highest values of the net return from the water unit was obtained from the $4^{\text {th }}$ treatment $\left(1.91\right.$ and $2.55 \mathrm{LE} / \mathrm{m}^{3}$ water), as well as, the economic efficiency (1.043 and 1.443). This is due to the highest productivity in both seasons under the $4^{\text {th }}$ treatments.

\section{Conclusion}

It could be concluded that escaping irrigation at 60 DAS, during the physiological maturity stage $\left(\mathrm{T}_{4}\right)$ is the best treatment compared with the other treatments. It increased oil and seed yield and achieved the highest net return and economic efficiency.

\section{References}

Ali, Md. H. and Shui, L.T.(2009) Potential evapotranspiration model for Muda Irrigation Project, Malaysia. Water Resour. Manage. 23: 57-69.

A.O.A.C. (2005) "Official Methods of Analysis of AOAC International", $18^{\text {th }}$ ed., AOAC International, Gaithersburg, MD, USA, Official Methods 2005 - 08.

Beyazgul, M., Kayam, Y. and Engelsman, F. (2000) Estimation methods for crop water requirements in the Gediz Basin of western Turkey. Journal of Hydrology 229: 1926 .

Browne, C.L. (1977) Effect of date of final irrigation on yield and yield components of sunflowers in semiarid environment. Aust. J. Exp. Agric. Anim. Hush. 17: 482-488.

Doorenbos, J. and Kassam, A.H. (1979) Yield response to water. Irrigation and drainage paper 33. In: “Booker Tropical Soil Manual”, J.R. Landon (Ed.), Longman Inc., New York, U.S.A.

Egypt. J. Soil Sci. 53, No. 1 (2013) 
Duncan, B.D. (1955) Multiple range and multiple F. Tests. Biometrics 11: 1-42.

English, M.J. (1990) Deficit irrigation. I. analytical framework. J. Amer. Soc. Civil Eng. 116 (IR3): 399-412.

English, M.J. and Raja, S.N. (1996) Perspectives on deficit irrigation. Agric. Water Manag. 32: 1-14.

Gomez, K.A. and Gomez, A.A. (1984) In: "Statistical Procedures for Agricultural Research", $2^{\text {nd }}$ ed., John Wiley and Sons, New York.

Karam, F., Lahoud, R., Masaad, R., Kabalan, R., Breidi, J., Chalita, C. and Rouphael, Y. (2007) Evapotranspiration, seed yield and water use efficiency of drip irrigated sunflower under full and deficit irrigation conditions. Agricultural Water Management 90 (3): 213-223.

Kazemeini, S.A., Edalat, M. and Shekoofa, A. (2009) Interaction effects of deficit irrigation and row spacing on sunflower (Helianthus annuus L.) growth, seed yield and oil yield. African J. of Agric. Res. 4 (11): 1165-1170.

Kirda, C., Moutonnet, P., Hera, C. and Nielsen, D. R. (1999) Crop yield response to deficit irrigation. Kluwer Academic Publisher, Dordrecht.

Kirnak, H., Tas, I., Kaya, C. and Higgs, D. (2002) Effects of deficit irrigation on growth, yield, and fruit quality of eggplant under semi-arid conditions. Austr. J. Agric. Res. 53: 1367-1373.

Ministry of Agriculture and Land Reclamation (2006) Sunflower, Technical Bulletin No. 1020, Central Admin. of Agric. Exten., ARC, Giza, Egypt .

Rinaldi, M. (2001) Application of EPIC model for irrigation scheduling in southern Italy. Agric. Water Manag. 49: 185-196.

Smith, M., Kivumbi, D. and Heng, L.K. (2002) Use of the FAO-CROPWAT model in deficit irrigation studies. "Deficit Irrigation Practices", FAO Water Reports No. 22, Rome.

Stone, L. R., Schlege, A. J., Gwin, R. E. and Khan, A. H. (1996) Response of corn, grain sorghum, and sunflower to irrigation in the high plains of Kanasas. Agric. Water Manag. 30: 251-259.

Tan, S., Beyazgul, M., Avcieri, Z., Kayam, Y., and Kaya, H.G. (2000) Effect of irrigation at various growth stage on some economic characters of first crop sunflower. J. Aegean Agric. Res. Inst. 10: 1-34. 


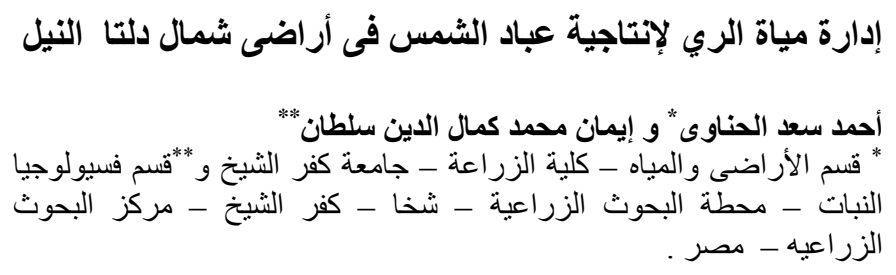

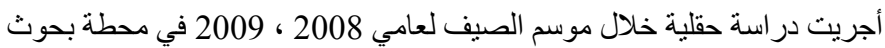

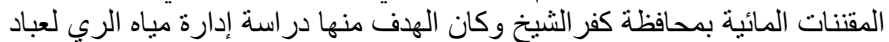

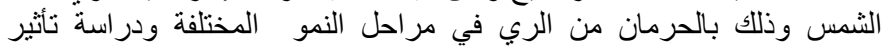

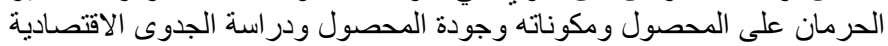

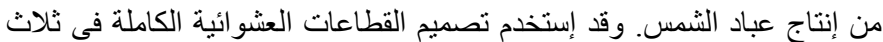

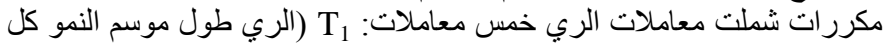

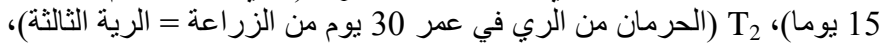
T T3

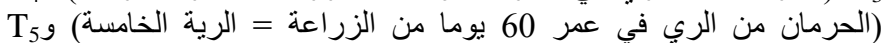

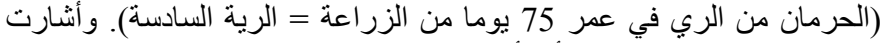

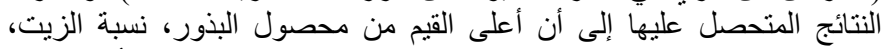

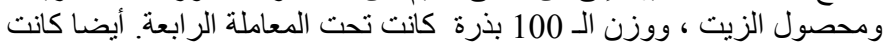

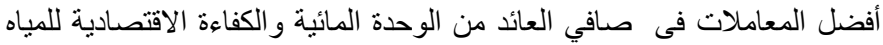

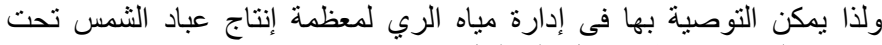
ظروف الدر اسة بمنطقة شمال دلتا النيل.

Egypt. J. Soil Sci. 53, No. 1 (2013) 